DOI 10.22460/infinity.v6i2.p177-182

\title{
THE RELATION BETWEEN SELF-EFFICACY TOWARD MATH WITH THE MATH COMMUNICATION COMPETENCE
}

\author{
Sylvia Rahmi ${ }^{1}$, Rifka Nadia ${ }^{2}$, Bibih Hasibah $^{3}$, Wahyu Hidayat ${ }^{4}$ \\ ${ }^{1}$ SMP Negeri 25 Pekanbaru, Jl. Kartama, Maharatu, Marpoyan Damai, Pekanbaru, Riau, Indonesia \\ ${ }^{2}$ SMP Negeri 10 Banda Aceh, JL. Poteumereuhom, Kuta Alam, Banda Aceh, Indonesia \\ ${ }^{3}$ SMP Negeri 1 Soreang, Jl. Ciloa No. 3, Pamekaran, Soreang, Bandung, Indonesia \\ ${ }^{4}$ STKIP Siliwangi, Jl. Terusan Jenderal Sudirman, Cimahi, Indonesia \\ 1 sylviarahmi.sr@gmail.com, ${ }_{4}^{2}$ rifkanadia28@yahoo.com, ${ }^{3}$ bibih_hasibah@yahoo.com, \\ ${ }^{4}$ wahyu@ stkipsiliwangi.ac.id
}

Received: June 08, 2017 ; Accepted: September 11, 2017

\begin{abstract}
The aim of this research is to analyze the relationship between self-efficacy toward mathematics with mathematical communication competence. The design of this research is survey and correlation technique. The research instruments used in this research are math communication competence test and attitude scale. The instruments used are 5 questions about math communication competenca teat and 28 statements about self-efficacy. The research population is all student of SMP Negeri 1 Soreang. With samples of this research were 70 students of 7 th grade student chosen by cluster random sampling. The data analyzed quantitatively done through math communication data and self-efficacy attitude scale. SPSS 20 used in this research. The result shows that student self-efficacy influences students math communication competence.
\end{abstract}

Keywords: Communication Skills Mathematics, Self-Efficacy.

\begin{abstract}
Abstrak
Penelitian ini bertujuan untuk menganalisis hubungan antara self-efficacy terhadap matematika dengan kemampuan komunikasi matematik. Desain penelitian ini adalah survey dengan teknik korelasi. Instrumen penelitian yang digunakan dalam penelitian ini berupa tes kemampuan komunikasi matematik dan skala sikap self-efficacy siswa. Intrumen yang digunakan yaitu 5 soal kemampan komunikasi matematik dan 28 pernyataan mengenai self-efficacy. Populasi dalam penelitian ini adalah seluruh siswa SMP Negeri 1 Soreang dengan sampel penelitian ini adalah 70 siswa kelas VII sebanyak dua kelas yang dipilih secara cluster random sampling. Analisis data dilakukan secara kuantitatif yang dilakukan terhadap data kemampuan komunikasi matematik dan skala sikap self-efficacy. dalam perhitungan statistik menggunakan SPSS 20, hasil penelitian menunjukkan bahwa self-efficacy siswa mempengaruhi kemampuan komunikasi matematik siswa.
\end{abstract}

Kata Kunci: Kemampuan Komunikasi Matematik, Self-Efficacy.

How to Cite: Rahmi, S., Nadia, R., Hasibah, B., \& Hidayat, W. (2017). The Relation between Self-Efficacy toward Math with the Math Communication Competence. Infinity, 6 (2), 177182. doi:10.22460/infinity.v6i2.p177-182 


\section{INTRODUCTION}

Education is one important aspects that will determine the quality of life of a person and a nation. In formal education, one of the subjects in school that can be used to build the students' way of thinking is mathematics. Therefore, math lessons at schools not only emphasize the giving formulas but also teach students to be able to communicate ideas related to everyday life.

One of the mathematical skills that must be possessed by the students is the ability of mathematical communications. Mathematical communication can be interpreted as a student's ability to convey something he knows through dialogue events or interrelationships that occurr in the classroom environment, where there is a transfer of the message. Displaced messages contain mathematical materials that learn, such a concepts, formulas, or a problemsolving strategies. Parties involved in communication events in the classroom are teacher and student. The way the message can be transmitted can be smoken or written.

In order for student's mathematical communication skills to develop well, then in the process of learning mathematics, teachers need to provide opportunities for students to be able to improve their ability to communicating mathematical ideas. Pimm (Lindawati, 2013) states that children are given the opportunity to work in a groups in collecting and presenting data, show good progress as they listen to one anothers's ideas, discuss it together and then draw up the conclusions that the group views. Apparently they learn most from communicating and constructing their own knowledge.

According Anggraeni (2013) summarizes the opinions of some experts and NCTM and identifies some mathematical communication skills such as: a) stating a situation, into drawings, diagrams, language, symbols, expressions or mathematical models; b) State image, diagrams, language, symbols, expressions or mathematical models in their own language; c) Listening, discussing, writing mathematics; d) Read a mathematical presentation with understanding; e) Revisit a mathematical description in its own language; and f) Compile questions about mathematics.Through mathematical communication students exchange and explain their ideas or understanding to their friend. The communication process helps students construct the meaning of a series of mathematical processes and make generalizations. In an effort to explore and develop students' mathematical communication skills, teachers should expose students to a variety of contextual issues and invite them to communicate their respective ideas (Hidayat, 2017). In the 2013 curriculum also said that in mathematics learning hard skills and soft skills including mathematics education values in the culture and character that should be developed simultaneously and balanced through learning scientific approach. One of the soft skills that mathematics is self-efficacy. Self-efficacy leads to a person's beliefs about its ability to organize and carry out a series of actions to achieve results (Bandura, 1997). It can be concluded self-efficacy is the belief that students need to have in order to succeed in the learning process.

Pintrich and De Groot (Khaerunisak, Kartono, Hidayah, and Fahmi, 2017) found that students who believed they could perform academic tasks using cognitive and metacognitive strategies were more and still doing better than unbelieving students. Self-efficacy makes a difference in the way people act, as a follow-up of feelings and thoughts. People who believe they can do something that has the potential to transform environmental events are more likely to act and more likely to succeed than those with low self-efficacy. Behavior is influenced by the extent to which a person believer can perform the actions required by the particular situation. 


\section{METHOD}

This research design is a survey by using correlation technique, where writer take two class as sample of research. This research conducted in SMP Negeri 1 Soreang. The development of self-efficacy variables students about math starting with the 28-point declaration preparation is complete with 4 choices. The scale used is a Likert scale. With a choice of answers SS (strongly agree), S (agree), TS (disagree), and STS (strongly disagree). For determination calculations using score $\mathrm{SS}=4, \mathrm{C}=3$, TS $=2$, and STS $=1$ for statements favorable (positive), whereas a score $\mathrm{SS}=1, \mathrm{~S}=2, \mathrm{TS}=3$, and $\mathrm{STS}=4$ for statements unfavorable (negative). The instrument was then consulted with the supervisor in order to have the validity of the content. Meanwhile, in order to have the empirical validity of the instrument is then tested to determine the validity, reliability, distinguishing power and distress index. Math test used was a test of mathematical communication skills.

The test of mathematical communication ability is arranged in the form of description. The reason for preparation of the test in the form of description because it is tailored to the purpose of this study which prioritizesthe process of the results. Tests in the form of description is not much to give a chance to speculate, it can even encourage students to dare to express their opinions in their own and language. The steps taken in the preparation of this instrument is (1) Make a grid of test based indicators matematic communication skills, (2) Make the scoring guidelines, (3) Preparing test problems; (4) Assess conformity between material, indicators and test questions.

\section{RESULTS AND DISCUSSION}

\section{Results}

To see how strong the relationship between self-efficacy and mathematical communication skills, then the correlation test Pearson with $\alpha=0.05$ and the hypothesis is

$\mathrm{H}_{0:} \rho=0$

$\mathrm{H}_{1:} \rho \neq 0$

with the criteria:

if $\operatorname{sig}>0.05$ then $\mathrm{H}_{0}$ accepted

Table1. Correlation Guildfrord's Criteria

\begin{tabular}{cc}
\hline Range & Criteria \\
\hline 0.01 to 0.20 & very weak \\
0.20 to 0.40 & Weak \\
0.40 to 0.70 & Strong Enough \\
0.70 to 0.90 & Strong \\
0.90 to 1.00 & Very strong \\
\hline
\end{tabular}


Table 2. Results of self-efficacy Correlation and Mathematical Communication Skills

\begin{tabular}{cccc}
\hline & & self efficacy & posttest \\
\hline \multirow{2}{*}{ Pearson Correlation } & self-efficacy & 1,000 & 0,424 \\
& postes & 0,424 & 1,000 \\
\hline \multirow{2}{*}{ Sig. (One-tailed) } & self-efficacy & 1,000 & 0,000 \\
& postes & 0,000 & 1,000 \\
\hline \multirow{2}{*}{$\mathbf{N}$} & self efficacy & 70 & 70 \\
& postes & 70 & 70 \\
\hline
\end{tabular}

Based on Table 2, the result of correlation between self-efficacy dam mathematical communication ability of students is 0.424 and the significance value (sig) of 0.000 . Correlation values (r) obtained was 0.424 , which means is quite powerful. Due to the significant value of 0,000 is smaller than $\alpha=0.05, \mathrm{H}_{0}$ is rejected, meaning that there is a relationship between self-efficacy toward mathematics with mathematical communication skills.

To determine the influence ofanatar self-efficacy with mathematical communication skills then tested using a regression coefficient of linear regression analysis. This analysis was conducted to see the direct influence of self-efficacy of students' mathematical communication abilities of students. The hypothesis tested were:

$\mathrm{H}_{0}$ : Self-Efficacy students about math does not affect students' mathematical communication skills

$\mathrm{H}_{1}$ : Self-Efficacy affects students about math mathematical communication skills of students

with criteria:

if sig> 0.05 then $\mathrm{H}_{0}$ accepted

results of the analysis are shown in Table 3

Table 3. Regression analysis Self-efficacy with Communication Capabilities of Mathematical

\begin{tabular}{ccccccc}
\hline Model & \multicolumn{2}{c}{$\begin{array}{c}\text { Unstandardized } \\
\text { Coefficients }\end{array}$} & \multicolumn{2}{c}{$\begin{array}{c}\text { Standardized } \\
\text { Coefficients }\end{array}$} & T & Sig. \\
\cline { 3 - 5 } & B & Std. Error & Beta & & \\
\hline 1 & (Constant) & 72,888 & 2,935 & & 24,832 & 0,000 \\
& postes & 0,190 & 0,049 & 0,424 & 3,865 & 0,000 \\
\hline
\end{tabular}

Based on Table 3, it can be seen the regression equation $\mathrm{Y}=72.888+0,190 \mathrm{x}$ which means, the greater the value of self-efficacy,the greater the students' mathematical communication skills of students, and vice versa. Because the significance value of 0.000 is smaller than $\alpha=$ 0.05 , it can be concluded under $\mathrm{H}_{0}$ is rejected it means significantly Self-efficacy affects students toward math mathematical communication skills of students.

\section{Discussion}

Based on the analysis of data to test the hypothesis, the conclusions from the findings made by that self-efficacy of students towards mathematics in general affect students' mathematical communication skills. Self-efficacy affects the ability of mathematical communications 
because a higher level of confidence in one's self to the higher mathematics mathematical communication skills. This is shown by the significant value of 0.024 , which means smaller than $\alpha=0.05$, which means self-efficacy affect the ability of mathematical communications. The correlation coefficient of 0.380 and a positive value indicating that a positive relationship and have the power relationships within the category of being between two variables. This supports the hypothesis that there is evidence of the relationship between self-efficacy toward mathematics with mathematical communication skills. Self-efficacy is one of the factors that influence the adjustment to the ability of the student (Sumarmo, Hidayat, Zulkarnaen, Hamidah, \& Sariningsih, 2012; Irfan \& Suprapti, 2014; Haji \& Abdullah, 2016; Hendriana, 2017). In addition, the results are also in line with those proposed by Hendriana, Rohaeti \& Hidayat (2016) that mathematical communication ability is also influenced by various factors, including self-efficacy factor.

\section{CONCLUSION}

Based on the analysis the conclusion is: (1) there is a relationship between self-efficacy toward mathematics with mathematical communication skills. (2) self-efficacy influences students toward math mathematical communication skills.

\section{REFERENCES}

Anggraeni, D. (2013). Meningkatkan Kemampuan Pemahaman dan Komunikasi Matematik Siswa SMK melalui Pendekatan Kontekstual dan Strategi Formulate-Share-Listen-Create (FSLC). Infinity Journal, 2(1), 1-12.

Bandura (1997). Self-efficacy: The Excercise of Control. New York: W.H Freeman and Company.

Hendriana, H., Rohaeti, E. E., \& Hidayat, W. (2016). Metaphorical Thinking Learning and Junior High School Teachers' Mathematical Questioning Ability. Journal on Mathematics Education, 8(1), 55-64.

Hendriana, H. (2017). Senior High School Teachers' Mathematical Questioning Ability and Metaphorical Thinking Learning. Infinity Journal, 6(1), 51-58.

Hidayat, W. (2017). Adversity Quotient dan Penalaran Kreatif Matematis Siswa SMA dalam Pembelajaran Argument Driven Inquiry pada Materi Turunan Fungsi. KALAMATIKA Jurnal Pendidikan Matematika, 2(1), 15-28.

Irfan, M., \& Suprapti, V. (2014). Hubungan Self-Efficacy dengan Penyesuaian Diri Terhadap Perguruan Tinggi Pada Mahasiswa Baru Fakultas Psikologi Universitas Airlangga. Jurnal Psikologi Pendidikan dan Perkembangan, 3(3), 172-178.

Khaerunisak, K., Kartono, K., Hidayah, I., \& Fahmi, A. Y. (2017). The Analysis of Diagnostic Assesment Result in Pisa Mathematical Literacy Based on Students SelfEfficacy in RME Learning. Infinity Journal, 6(1), 77-94.

Lindawati, S. (2013). Pembelajaran Matematika dengan Pendekatan Inkuiri Terbimbing Untuk Meningkatkan Kemampuan Pemahaman dan Komunikasi Matematis Siswa Sekolah Menengah Pertama. Jurnal Pendidikan, 2(2), 16-29.

Haji, S., \& Abdullah, M. I. (2016). Peningkatan Kemampuan Komunikasi Matematik Melalui Pembelajaran Matematika Realistik. Infinity Journal, 5(1), 42-49. doi:http://dx.doi.org/10.22460/infinity.v5i1.190 
182 Rahmi, Nadia, Hasibah, \& Hidayat, The Relation between Self-Efficacy toward Math ...

Sumarmo, U., Hidayat, W., Zukarnaen, R., Hamidah, M., \& Sariningsih, R. (2012). Kemampuan dan Disposisi Berpikir Logis, Kritis, dan Kreatif Matematik (Eksperimen terhadap Siswa SMA Menggunakan Pembelajaran Berbasis Masalah dan Strategi ThinkTalk-Write). Jurnal Pengajaran MIPA, 17(1), 17-33. 